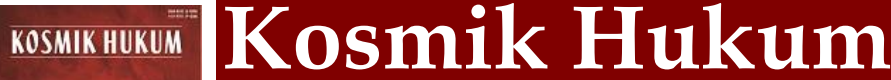

\author{
Fakultas Hukum
}

Universitas Muhammadiyah Purwokerto

Vol. 20 No. 2 (2020)

This work is licensed under a Creative Commons Attribution 4.0 International License (cc-by)

\section{Perlindungan Konsumen atas Penggunaan Bahan Tambahan Pangan pada Makanan dan Minuman}

\author{
Hanari Fajarini ${ }^{1 凶}$, Anggray Duvita Wahyani $^{2}$ \\ 1,2 Fakultas Ilmu Kesehatan Universitas Muhadi Setiabudi \\ E-mail: hanari.fajarini@gmail.com
}

\begin{abstract}
Food circulation that does not meet health standards is generally caused by the desire of producers to get the maximum profit by neglecting consumer safety. Lack of legal protection for consumers results in consumers in a weak position. The purpose of this study was to determine how the legal protection of consumers for the use of food additives. The method or approach used in this research is sociological with a qualitative paradigm, in which sociology is an approach with the aim of studying and examining the existence of a phenomenon of reciprocal relations between law and other social institutions in which law is not conceptualized as a form of independent (autonomous) normative symptoms., but as a social institution which is related significantly to other variables. The results showed that $80 \%$ of business operators use synthetic dyes, while only $20 \%$ of business operators use natural dyes. Meanwhile, the results of interviews with consumers showed that $63.33 \%$ of the consumer's benchmark in choosing food was food with a more striking color, while $36.67 \%$ of consumers chose food that had no striking color. The results showed that to protect consumers from the use of food additives, there are several efforts that can be made, namely supervision, guidance and consumer education. The conclusion of this research is to realize legal protection for consumers, every food product is required to meet food safety and quality standards, as regulated in Article 111 of the Law on Health.
\end{abstract}

Keywords: food, food additives, consumer protection

\begin{abstract}
Abstrak
Peredaran pangan yang tidak memenuhi standar kesehatan pada umumnya disebabkan keinginan produsen agar mendapat keuntungan sebanyak-banyaknya dengan mengesampingkan keselamatan konsumen. Kurangnya perlindungan hukum terhadap konsumen mengakibatkan konsumen berada pada posisi yang lemah. Tujuan penelitian ini untuk mengetahui bagaimana perlindungan hukum terhadap konsumen atas penggunaan bahan tambahan pangan. Metode atau pendekatan yang digunakan dalam penelitian ini adalah sosiologis dengan paradigma kualitatif, yang mana sosiologis merupakan pendekatan dengan tujuan mempelajari dan meneliti adanya suatu fenomena hubungan timbal balik antara hukum dan lembaga sosial yang lain di mana hukum tidak dikonsepkan sebagai bentuk gejala normatif mandiri (otonom), melainkan sebagai suatu institusi sosial yang dikaitkan secara nyata dengan variabel-variabel yang lain. Hasil penelitian menunjukkan bahwa $80 \%$ pelaku usaha menggunakan pewarna sintetis, sedangkan hanya $20 \%$ pelaku usaha yang menggunakan pewarna alami. Sementara itu hasil wawancara dengan konsumen menunjukkan bahwa 63,33 \% tolok ukur konsumen dalam memilih makanan adalah makanan yang lebih mencolok warnanya, sedangkan $36,67 \%$ konsumen memilih makanan yang tidak mencolok warnanya. Hasil penelitian menunjukkan bahwa untuk melindungi konsumen dari penggunaan bahan tambahan pangan, ada beberapa upaya yang dapat dilakukan yaitu pengawasan, pembinaan dan pendidikan konsumen. Kesimpulan dari penelitian ini adalah untuk mewujudkan perlindungan hukum bagi konsumen maka setiap produk pangan wajib memenuhi standar keamanan dan mutu pangan, sebagaimana diatur dalam Pasal 111 Undang-Undang tentang Kesehatan.
\end{abstract}

Kata kunci: pangan, bahan tambahan pangan, perlindungan konsumen

Copyright@2020KosmikHukum. All rights reserved.

\section{Pendahuluan}

Pangan menurut Pasal 1 Undang-Undang Nomor 7 Tahun 1996 tentang Pangan adalah segala sesuatu yang berasal dari sumber hayati dan air, baik yang diolah maupun tidak diolah, yang diperuntukkan sebagai makanan atau minuman bagi konsumsi manusia, termasuk bahan 
Kosmik Hukum Vol. 20 No. 2 (2020): 91-103

E-ISSN: 2655-9242 | P-ISSN: 1411-9781

DOI: $10.30595 /$ kosmikhukum.v20i2.6883

tambahan pangan, bahan baku pangan, dan bahan lain yang digunakan dalam proses penyiapan, pengolahan, atau pembuatan makanan dan minuman.

Keamanan pangan di Indonesia masih jauh dari kata aman. Beberapa masalah yang berkaitan dengan keamanan pangan di Indonesia misalnya: ${ }^{1}$

1. Ditemukan beberapa produk pangan yang tidak memenuhi persyaratan mutu dan keamanan, karena penggunaan bahan tambahan pangan sintetik yang dilarang, pencampuran dengan bahan kimia yang berbahaya, masa kadaluarsa yang tidak diperhatikan dan lain-lain.

2. Pemberian label dan iklan produk pangan yang tidak memenuhi syarat.

3. Rendahnya pengetahuan, ketrampilan dan tanggung jawab produsen pangan tentang mutu dan keamanan pangan, terutama industri kecil dan industri rumah tangga.

4. Masih rendahnya kepedulian konsumen tentang mutu dan keamanan pangan, terutama karena terbatasnya pengetahuan dan rendahnya kemampuan daya beli untuk produk pangan yang bermutu dan tingkat keamanan tinggi.

Peredaran pangan yang tidak memenuhi standar kesehatan tersebut pada umumnya disebabkan keinginan produsen agar mendapat keuntungan sebanyak-banyaknya dengan mengesampingkan keselamatan konsumen. Sementara itu tingkat pengetahuan konsumen dan perlindungan hukum terhadap konsumen dalam bidang pangan masih rendah. Perlindungan konsumen merupakan satu kesatuan dalam kegiatan bisnis yang sehat. Dalam kegiatan bisnis yang baik dan sehat terdapat keselarasan perlindungan hukum antara konsumen dengan produsen. Tidak adanya keselarasan perlindungan hukum menyebabkan konsumen berada pada posisi yang lemah, terlebih lagi jika produk yang dihasilkan oleh produsen merupakan jenis produk yang terbatas. Kerugian yang konsumen alami ditimbulkan sebagai akibat dari adanya hubungan hukum perjanjian antara produsen dengan konsumen, maupun akibat dari adanya perbuatan melanggar hukum yang dilakukan oleh produsen. ${ }^{2}$

Pada dasarnya pemerintah telah menyatakan secara tegas dalam Undang Undang No. 8 Tahun 1999 tentang Perlindungan Konsumen Pasal 1 butir (2) bahwa Konsumen adalah setiap orang pemakai barang dan/atau jasa yang tersedia dalam masyarakat, baik dari kepentingan diri sendiri, keluarga, maupun makhluk hidup lain yang tidak untuk diperdagangkan. Dari penjelasan pasal 1 butir (2) dapat difahami sejatinya peran konsumen sangatlah vital dalam sistem rantai peredaran barang dan jasa, yang mana dalam hal ini sebagai target dan sosok penentu akan kelangsungan para pelaku usaha itu sendiri. ${ }^{3}$

Undang-Undang Perlindungan Konsumen Nomor 8 Tahun 1999 Tentang Perlindungan Konsumen menjelaskan bahwa hak konsumen diantaranya adalah hak atas kenyamanan, keamanan dan keselamatan dalam mengkomsumsi barang dan/atau jasa; hak untuk memilih barang dan/atau jasa tersebut sesuai dengan nilai tukar dan kondisi serta jaminan yang dijanjikan; hak atas informasi yang benar, jelas dan jujur mengenai kondisi dan jaminan barang dan/atau jasa; hak untuk didengar pendapat dan keluhannya atas barang dan/atau jasa yang digunakan; hak untuk mendapatkan advokasi, perlindungan dan upaya penyelesaian sengketa perlindungan konsumen secara patut; hak untuk mendapatkan pembinaan dan pendidikan; hak untuk diperlakukan secara benar, jujur dan tidak diskriminatif; hak mendapatkan kompensasi, ganti rugi dan/atau penggantian, apabila barang dan atau jasa yang diterima terdapat ketidaksesuaian antara perjanjian dengan yang diterima konsumen atau tidak

Siti Fatimah, 2015, Skripsi : Perlindungan Hukum Hak Atas Informasi Dan Keamanan Dalam Mengkonsumsi Makanan Yang Mengandung Zat Pewarna Tekstil Rhodamin B Berdasarkan Undang- Undang Nomor 8 Tahun 1999 Tentang Perlindungan Konsumen Di Kota Yogyakarta, UIN Sunan Kalijaga, Yogyakarta, hlm. 2

2 Sahmadi Miru, 2013, Prinsip-Prinsip Perlindungan Hukum Bagi Konsumen Di Indonesia, Rajawali Pers, Jakarta, hlm.1.

3 Imam Adi Sanjaya, 2018, Perlindungan Hukum Komsumen Terhadap Produk Yang Tidak Bersersertifikat (Studi Di Dinas Perdagangan Dan Dinas Pertanian Dan Ketahanan Pangan Kota Malang), Jurusan Hukum Bisnis Syariah Fakultas Syariah Universitas Islam Negeri Maulana Malik Ibrahim Malang, hlm. 4 
sebagaimana mestinya; serta hak-hak lain yang telah diatur dalam ketentuan peraturan perundang-undangan lainnya. ${ }^{4}$

Demi memenuhi persaingan usaha dan dalam upaya menjaga stabilitas dalam perdagangan, tak sedikit pelaku usaha melakukan persaingan dengan cara yang tidak sehat terlebih untuk produk makanan dan minuman, salah satunya dengan menambahkan bahan tambahan pangan pada produk makanan atau minuman yang diproduksi. Penggunaan bahan tambahan pangan pada makanan dan minuman semakin meningkat, terutama setelah adanya penemuan-penemuan baru dan keberhasilan dalam menyintesis bahan kimia baru yang lebih praktis, lebih murah, dan lebih mudah diperoleh, penambahan bahan tambahan atau zat aditif ke dalam makanan merupakan hal yang dipandang perlu untuk meningkatkan mutu suatu produk sehingga mampu bersaing di pasaran. ${ }^{5}$

Bahan Tambahan Pangan menurut Peraturan Menteri Kesehatan RI Nomor 33 Tahun 2012 adalah bahan yang ditambahkan kedalam pangan untuk mempengaruhi sifat atau bentuk pangan. Termasuk didalamnya adalah pewarna, penyedap rasa dan aroma, pengawet, dan pengental. Menurut Peraturan Kepala Badan Pengawas Obat dan Makanan RI No.4 Tahun 2014 mengenai nama bahan tambahan pangan, atau jenis bahan tambahan pangan adalah nama kimia/generik/umum/lazim yang digunakan untuk identitas bahan tambahan pangan dalam bahasa Indonesia atau bahasa Inggris.

Pada awalnya bahan tambahan pangan berasal dari alam berupa tumbuh- tumbuhan yang selanjutnya disebut bahan tambahan pangan alami yang tidak menimbulkan efek samping yang membahayakan kesehatan manusia. ${ }^{6}$ Kondisi demikian menjadi dilema dikarenakan jumlah penduduk bumi yang semakin bertambah menuntut jumlah makanan yang lebih besar sehingga bahan tambahan pangan alami tidak mencukupi lagi. Berangkat dari fenomena tersebut, pada akhirnya mendorong industri makanan memproduksi makanan yang memakai bahan tambahan pangan buatan (sintetis). Pembuatannya dengan cara mereaksikan zat-zat kimia. Penggunaan bahan tambahan pangan sintetis yang berlebihan dapat menimbulkan beberapa efek samping misalnya: gatal- gatal, reaksi alergi, gangguan pencernaan, kanker dan lain-lain. ${ }^{7}$ Dengan adanya fenomena ini, penulis tertarik untuk melakukan research dalam upaya menemukan kepastian hukum dengan judul Perlindungan Konsumen atas Penggunaan Bahan Tambahan Pangan pada Makanan dan Minuman. Rumusan masalah dari penelitian ini adalah bagaimana perlindungan hukum terhadap konsumen atas penggunaan bahan tambahan pangan? Sedangkan tujuan dari penelitian ini adalah untuk mengetahui bagaimana perlindungan hukum terhadap konsumen atas penggunaan bahan tambahan pangan.

\section{Metodologi Penelitian}

Penelitian hukum atau legal research dalam bahasa inggris, dan dalam bahasa Belanda rechtsonderzoek adalah sebagai suatu proses guna menemukan suatu aturan hukum, prinsipprinsip hukum, maupun doktrin-doktrin hukum dalam menghadapi isu hukum yang dihadapi. ${ }^{8}$ Tentunya tak lepas dari unsur keterkaitan dengan penelitian tentang sistematika hukum, penelitian tentang asas-asas hukum, penelitian tentang taraf sinkronisasi peraturan

4 Endang Sutrisno and Hanari Fajarini, Legal Culture Of Pharmacist In The Perspective Of Pharmaceutical Services Standard In Pharmacies, Jurnal Dinamika Hukum, Fakultas Hukum Universitas Jenderal Soedirman, Volume 16, Number 2, September 2016, Hlm. 153

5 Nurdin Nurdin dan Budi Utomo, Tinjauan Penggunaan Bahan Tambahan Pangan Pada Makanan Jajan Anak Sekolah, Jurnal Riset Kesehatan, Volume 7 Nomor 2, 2018, hlm. 85

6 Endar Puspawiningtyas, Regawa Bayu Pamungkas, Alwani Hamad, Upaya Meningkatkan Pengetahuan Bahan Tambahan Pangan Melalui Pelatihan Deteksi Kandungan Formalin dan Boraks, Jurnal Pengabdian dan Pemberdayaan Masyarakat (JPPM), Universitas Muhammadiyah Purwokerto, Volume 1 Nomor 1, Maret 2017

7 Leha Julaeha, Ai Nurhayati, Ai Mahmudatussa'adah, Penerapan Pengetahuan Bahan Tambahan Pangan Pada Pemilihan Makanan Jajanan Mahasiswa Pendidikian Tata Boga UPI, Jurnal Media Pendidikan, Gizi dan Kuliner, Volume 5 Nomo 1, April 2016, hlm. 18

8 Peter Mahmud Marzuki, 2005, Penelitian Hukum, Prenada Media, Jakarta, hlm.35 
Kosmik Hukum Vol. 20 No. 2 (2020): 91-103

E-ISSN: 2655-9242 | P-ISSN: 1411-9781

DOI: $10.30595 /$ kosmikhukum.v20i2.6883

perundang-undangan, peraturan tentang perbandingan hukum, dan peraturan tentang sejarah hukum. Berdasarkan fenomana atau isu hukum dalam penelitian ini, maka pendekatan yang digunakan dalam penelitian ini adalah sosiologis dengan paradigma kualitatif, yang mana sosiologis merupakan pendekatan dengan tujuan mempelajari dan meneliti adanya suatu fenomena hubungan timbal balik antara hukum dan lembaga sosial yang lain di mana hukum tidak dikonsepkan sebagai bentuk gejala normatif mandiri (otonom), melainkan sebagai suatu institusi sosial yang dikaitkan secara nyata dengan variabel-variabel yang lain. ${ }^{9}$ Sedang kualitatif sendiri merupakan suatu metode penelitian yang memusatkan perhatiannya, eksplorasi, dan memahami pada prinsip-prinsip umum yang mendasari perwujudan satuansatuan gejala. ${ }^{10}$

\section{Hasil dan Pembahasan}

\section{A. Hasil Penelitian}

Hasil wawancara penulis dengan 10 orang pedagang atau pelaku usaha yang menggunakan bahan tambahan pangan atau zat aditif pada makanan dan minuman yang dijualnya. Pewarna yang digunakan oleh pedagang atau pelaku usaha tersebut berbeda-beda, ada yang menggunakan pewarna alami maupun pewarna sintetis. Jenis pewarna yang digunakan pelaku usaha tersebut dapat dilihat pada tabel 3 berikut:

Tabel. 1

Jenis pewarna yang digunakan oleh pelaku usaha.

\begin{tabular}{cccc}
\hline No & Pewarna & $\begin{array}{c}\text { Jumlah } \\
\text { Konsumen }\end{array}$ & Presentase \\
\hline 1 & Alami & 2 & $20 \%$ \\
2 & Sintetiis & 8 & $80 \%$ \\
\hline \multicolumn{2}{l}{ Jumlah } & $\mathbf{1 0}$ & $\mathbf{1 0 0 \%}$ \\
\hline
\end{tabular}

Tabel tersebut menunjukkan bahwa $80 \%$ pelaku usaha menggunakan pewarna sintetis, sedangkan hanya $20 \%$ pelaku usaha yang menggunakan pewarna alami. Pewarna sintetis yang digunakan oleh pelaku usaha tersebut merupakan pewarna sintetis yang diizinkan ditambahkan pada makanan, akan tetapi penggunaan pewarna sintetis tersebut dibatasi penggunaannya, karena pada dasarnya, pewarna sintetis yang masuk kedalam tubuh manusia akan menimbulkan efek bagi kesehatan jika digunakan secara terus menerus. Dari hasil wawancara penulis dengan pelaku usaha-pelaku usaha tersebut yang menggunakan pewarna sintetis menyatakan bahwa pewarna sintetis tersebut lebih mudah didapatkan dan lebih murah, penggunaannya juga sangat praktis dan warnanya lebih stabil dibandingkan dengan pewarna alami meskipun telah melalui proses pengolahan dan pemanasan. Sedangkan pelaku usaha yang menggunakan pewarna alami menyatakan bahwa dengan menggunakan pewarna alami lebih aman dan tidak akan menimbulkan efek negatif bagi kesehatan konsumen meskipun dikomsumsi secara terus menerus.

Sedangkan konsumen dalam memilih makanan yang akan dibelinya, hal pertama yang mereka perhatikan adalah warna dari makanan tersebut. karena warna juga merupakan tolok ukur dari kesegaran makanan. Tolok ukur yang diperhatikan oleh konsumen dapat dilihat pada tabel 2 berikut:

Tabel. 2

Tolok ukur konsumen dalam memilih warna makanan

\begin{tabular}{cccc}
\hline No & Tolok ukur warna & $\begin{array}{c}\text { Jumlah } \\
\text { Konsumen }\end{array}$ & Presentase \\
\hline 1 & Lebih mencolok & 19 & $63,33 \%$
\end{tabular}

Ronny Hanitijo Soemitro, 1999, Metodologi Penelitian Hukum dan Jurimetri, Ghalia Indonesia, Jakarta, hlm. 34

Burhan Ashshofa, 2004, Metode Penelitian Hukum, Rineka Cipta, Jakarta, hlm. 20-21 


\begin{tabular}{llcc}
2 & Tidak mencolok & 11 & $36,67 \%$ \\
\hline & Jumlah & $\mathbf{3 0}$ & $\mathbf{1 0 0 \%}$ \\
\hline
\end{tabular}

Tabel tersebut menunjukkan bahwa 63,33 \% tolok ukur konsumen dalam memilih makanan adalah makanan yang lebih mencolok warnanya, sedangkan 36,67\% konsumen memilih makanan yang tidak mencolok warnanya. konsumen yang memilih makanan yang lebih mencolok warnanya menyatakan bahwa makanan yang lebih mencolok warnanya lebih menarik kelihatanya dan lebih segar daripada makanan yang tidak mencolok, sedangkan konsumen yang memilih makanan yang tidak mencolok warnanya menyatakan bahwa makanan yang tidak mencolok warnanya lebih aman, dan untuk makanan yang warnanya lebih mencolok ditakutkan menggunakan pewarna sintetis yang digunakan untuk pewarna baju atau tekstil.

Hasil wawancara dengan Koordinator Bidang Umum Yayasan Lembaga Konsumen Kabupaten Brebes menyatakan bahwa untuk melindungi konsumen dari penggunaan zat aditif, ada beberapa upaya yang dapat dilakukan yaitu:

a. Pengawasan dan Pembinaan

Pengawasan dilakukan dengan cara memperhatikan jalur distribusi makanan dan survei-survei ke pasar, toko-toko swalayan maupun ke pabrik atau industri rumah tangga, sedangkan untuk pembinaan dilakukan dengan cara memperhatikan pihakpihak yang terkait dalam jalur distribusi makanan tersebut, seperti pelaku usaha. Pelaku usaha adalah salah satu yang harus diperhatikan, karena makanan-makanan yang dikomsumsi oleh konsumen berasal dari pelaku usaha. Kurangnya informasi mengenai penggunaan bahan tambahan pangan yang diizinkan dapat merugikan konsumen.

b. Pendidikan Konsumen

Adapun bentuk dari pendidikan konsumen ini seperti penyuluhan dan konsultasi. Penyuluhan yang dilakukan harus melibatkan beberapa pihak seperti pemerintah, dinas-dinas terkait, lembaga- lembaga swadaya masyarakat, pelaku usaha serta konsumen. Dengan harapan pihak-pihak yang terlibat dalam penyuluhan tersebut dapat menyampaikan informasi-informasi yang didapatkanya kepada pihak-pihak lain. Sedangkan pada saat konsultasi, konsumen diharapkan dapat memahami hakhaknya, bagaimana mereka dididik untuk mengajukan komplain dan bagaimana cara untuk menuntut hak-haknya yang tidak terpenuhi. Dijelaskan bahwa sebenarnya keberadaan Yayasan Lembaga Konsumen hanya untuk membantu pemerintah, membantu dalam hal memberikan pendidikan kepada konsumen, mendampingi konsumen yang merasa dirugikan untuk menuntut hak- haknya. Dan apabila ada konsumen yang mengadukan keluhan terhadap penggunaan zat aditif pada makanan dan tidak mendapat tanggapan dari pelaku usaha. Maka, konsumen dapat mengadukan kepada Yayasan Lembaga Konsumen, Lembaga Perlindungan Konsumen Swadaya Masyarakat serta Balai Besar Pengawas Obat dan Makanan.

\section{B. Pembahasan}

Mutu bahan pangan pada umumnya ditentukan oleh beberapa faktor, diantaranya rasa, bau, tekstur, nilai gizi dan lain sebagainya. Hanya saja sebelum faktor-faktor tersebut dipertimbangkan, pada umumnya konsumen cenderung menilai suatu produk dari tampilan warna secara visual. Semakin menarik warnanya maka konsumen akan semakin tertarik dengan produk pangan yang dijual. Selain sebagai faktor penentu mutu makanan, warna juga dijadikan sebagai indikator kesegaran dan kematangan suatu produk pangan. Baik tidaknya pengolahan makanan dapat ditandai dengan adanya warna yang seragam dan merata. ${ }^{11}$

11 Wisnu Cahyadi, 2009, Analisis dan Aspek Kesehatan Bahan Tambahan Pangan, Bumi Aksara, Jakarta, Hlm. 61. 
Kosmik Hukum Vol. 20 No. 2 (2020): 91-103

E-ISSN: 2655-9242 | P-ISSN: 1411-9781

DOI: $10.30595 /$ kosmikhukum.v20i2.6883

Akan tetapi, seringkali terjadi penyalahgunaan pemakaian zat pewarna yang peruntukannya bukan untuk makanan dan minuman, misalnya zat pewarna sintetis tekstil yang ditambahkan pada makanan atau minuman, hal ini sangat berbahaya bagi konsumen. Penyalahgunaan tersebut sering kali terjadi karena ketidaktahuan masyarakat tentang zat pewarna yang diizinkan digunakan untuk makanan, dan harga zat pewarna untuk industri lebih murah dibandingkan dengan harga zat pewarna untuk makanan, selain itu zat pewarna tekstil biasanya menghasilkan warna yang lebih menarik di bandingkan dengan zat pewarna untuk makanan. ${ }^{12}$

Pasal 1 Angka 5 Peraturan Kepala BPOM No. 37 Tahun 2013 tentang Batas Maksimum Penggunaan Bahan Tambahan Pangan Pewarna dijelaskan bahwa pewarna alami (Natural Food Colour) adalah pewarna yang dibuat melalui proses ekstraksi dan isolasi, ataupun derivatisasi (sintesis persial) dari bahan alam berupa tumbuhan, hewan, mineral atau sumber alami lainnya, termasuk pewarna identik alami. Ada beberapa pewarna alami serta batas penggunaan maksimum yang di jelaskan dalam peraturan kepala badan pengawas obat dan makanan ini. Batas maksimum penggunaanya dapat dilihat pada tabel 3 berikut:

Tabel. 3

Batas maksimum penggunaan pewarna alami.

\begin{tabular}{|c|c|c|}
\hline No & Pewarna & $\begin{array}{l}\text { Batas Maksimum } \\
\quad(\mathrm{mg} / \mathrm{kg})\end{array}$ \\
\hline 1 & Riboflavin (Riboflavins) & $0-0,5$ \\
\hline 2 & Kurkumin C.I.No 75300 (curcumin) & $0-3$ \\
\hline 3 & $\begin{array}{l}\text { Karmin dan ekstrak cochineal C.I.No. } 75470 \text { (carmines and } \\
\text { cochineal extract) }\end{array}$ & $0-5$ \\
\hline 4 & Klorofil C.I.No.75810 (chlorophyll) & Secukupnya \\
\hline 5 & $\begin{array}{l}\text { Klorofil dan klorofilin tembaga kompleks } \\
\text { (chlorophylls and chlorophyllins, copper complexes) }\end{array}$ & $0-15$ \\
\hline 6 & Karamel I (Caramel I-plain) & Secukupnya \\
\hline 7 & Karamel III amonia proses (Caramel III-ammonia process) & $\begin{array}{l}0-200 \text { untuk cair } \\
0-150 \text { untuk padat }\end{array}$ \\
\hline 8 & $\begin{array}{l}\text { Karamel IV amonia sulfit proses (Caramel IV-sulphite ammonia } \\
\text { process) }\end{array}$ & $\begin{array}{l}0-200 \text { untuk cair } \\
0-150 \text { untuk padat }\end{array}$ \\
\hline 9 & Karbon tanaman C.I.No. 77266 (Vegetable carbon) & Secukupnya \\
\hline 10 & Beta-Karoten/sayuran C.I.No. 75130 (Carotenes, beta (vegetable) & Secukupnya \\
\hline 11 & $\begin{array}{l}\text { Ekstrak anato (berbasis bixin) C.I.No. } 75120 \text { (Annatto extracts, } \\
\text { bixin based) }\end{array}$ & $0-12$ \\
\hline 12 & Karotenoid (Carotenoids) & $0-5$ \\
\hline 13 & Antosianin (Anthocyanins) & $0-2,5$ \\
\hline 14 & Titanium dioksida C.I.No.77891 (Titanium dioxide) & Secukupnya \\
\hline 15 & Merah Bit (Beet red) & Secukupnya \\
\hline
\end{tabular}

Sumber: Peraturan Kepala BPOM No. 37 Tahun 2013

Tabel 3 menunjukkan terdapat beberapa zat pewarna alami yang dibatasi penggunaannya sesuai dengan takaran per kilogramnya, akan tetapi ada juga zat pewarna yang batas penggunaannya menggunakan kata secukupnya atau sebanyak yang diperlukan. Penggunaan zat pewarna alami tersebut akan menambah nilai nutrisi atau gizi pada makanan

12 Chatarina Wariyah dan Sri Hartati Candra Dewi, Penggunaan Pengawet dan Pemanis Buatan Pada Pangan Jajanan Anak Sekolah (PJAS) di Wilayah Kabupaten Kulon Progo DIY, Agritech, Volume 33 Nomor 2, Mei 2013, hlm. 147 
serta aman jika ditambahkan pada makanan dan tidak akan mengganggu kesehatan. Sedangkan untuk pewarna sintetis (synthetic food colour) yang merupakan pewarna yang diperoleh secara sintesis kimiawi sesuai dengan ketentuan Pasal 1 Angka 6 Peraturan Kepala Badan Pengawas Obat dan Makanan tentang Batas Maksimum Penggunaan Bahan Tambahan Pangan Pewarna. Batas penggunaannya dapat dilihat pada tabel 4 berikut:

Tabel. 4

Batas penggunaan maksimum pewarna sintetis.

\begin{tabular}{clc}
\hline No & \multicolumn{1}{c}{ Pewarna } & $\begin{array}{c}\text { Batas } \\
\text { Maksimum } \\
(\mathbf{m g} / \mathbf{k g})\end{array}$ \\
\hline 1 & Tartrazin CI. No. 19140 (Tartrazine) & $0-7,5$ \\
2 & Kuning kuinolin CI. No. 47005 (Quinoline yellow) & $0-5$ \\
3 & Kuning FCF CI. No. 15985 (Sunset yellow FCF) & $0-4$ \\
4 & Karmoisin CI. No. 14720 (Azorubine (carmoisine)) & $0-4$ \\
5 & Ponceau 4R CI. No. 16255 (Ponceau 4R (cochineal red A)) & $0-4$ \\
6 & Eritrosin CI. No. 45430 (Erhythrosine) & $0-0,1$ \\
7 & Merah allura CI. No. 16035 (Allura red AC) & $0-7$ \\
8 & Indigotin CI. No. 73015 (Indigotine (indigo carmine)) & $0-5$ \\
9 & Biru berlian FCF CI. No. 42090 (Brilliant blue FCF) & $0-12,5$ \\
10 & Hijau FCF CI. No. 42035 (Fast green FCF) & $0-25$ \\
11 & Coklat HT CI.No. 20285 (Brown HT) & $0-1,5$ \\
\hline
\end{tabular}

Sumber: Peraturan Kepala BPOM No. 37 Tahun 2013

Tabel tersebut menunjukkan bahwa penggunaan zat pewarna sintetis dibatasi penggunaannya sesuai dengan takaran per kilogram makanan yang akan ditambahkan zat pewarna. Penggunaan zat pewarna sintetis ini akan berpengaruh bagi kesehatan jika digunakan secara terus menerus dan melebihi ambang batas penggunaan maksimumnya.

Prosedur untuk mengajukan pengaduan kepada Yayasan Lembaga Konsumen, serta mekanisme penanganannya yaitu sebagai berikut:[10]

1. Mengajukan pengaduan melalui telepon, surat atau datang langsung. Pengajuan melalui telepon dapat dikategorikan menjadi dua, yaitu:

a. hanya minta informasi atau saran (advice), maka telpon itu cukup dijawab secara lisan pula dan diberikan advice pada saat itu dan selesai

b. Pengaduan untuk ditindaklanjuti. Jika konsumen meminta pengaduannya ditindaklanjuti, maka si penelepon diharuskan mengirim surat pengaduan secara tertulis ke Yayasan Lembaga Konsumen yang berisi :

1) kronologis kejadian yang dialami sehingga merugikan konsumen;

2) wajib mencantumkan identitas dan alamat lengkap konsumen;

3) menyertakan barang bukti atau fotocopy dokumen pelengkap lainnya (kwitansi pembelian, kartu garansi, surat perjanjian, dll);

4) bukti bahwa konsumen telah melakukan komlain kepada pelaku usaha, namun tidak ditanggapi;

5) Mencantumkan tuntutan konsumen atas pengaduan yang dilakukan. 
Kosmik Hukum Vol. 20 No. 2 (2020): 91-103

E-ISSN: 2655-9242 | P-ISSN: 1411-9781

DOI: $10.30595 /$ kosmikhukum.v20i2.6883

2. Setelah surat masuk ke Yayasan Lembaga Konsumen, petugas mendaftarkan suratsurat yang masuk secara keseluruhan (register I). Tahap selanjutnya surat diserahkan kepada Pengurus Harian setidaknya ada tiga tindakan yang akan dilakukanyaitu (a) ditindaklanjuti atau tidak ditindaklanjuti (b) bukan merupakan sengketa konsumen (c) bukan merupakan skala prioritas. Kemudian surat didisposisikan ke Bidang Pengaduan Konsumen untuk dilakukan register II Khusus sebagai data dan dokumen pengaduan.

3. Setelah surat sampai ke personil yang menangani maka dilakukan seleksi administrasi berupa kelengkapan secara administrasi.

4. Setelah proses administrasi dan analisis substansi, yaitu korespondensi kepada pelaku usaha dan instansi terkait sehubungan dengan pengaduan konsumen. Pada tahap pertama korespondensi yang dilakukan adalah meminta tanggapan dan penjelasan mengenai kebenaran dan pengaduan konsumen tersebut. Di sini yayasan Lembaga Konsumen memberikan kesempatan untuk mendengarkan kedua belah pihak yaitu versi konsumen dan versi pelaku usaha. Banyak kasus sengketa antara produsen dan konsumen yang dapat diselesaikan dengan korespondensi ini, masing-masing pihak dengan memberikan jawaban surat secara tertulis ke Yayasan Lembaga Konsumen yang berisi klarifikasi ataupun permintaan maaf kepada konsumen.

5. Namun, tidak menutup kemungkinan dalam korespodensi ini masing-masing pihak tidak menjawab persoalan dan bersikukuh dengan pendapatnya. Dalam hal ini Yayasan Lembaga Konsumen mengambil inisiatif untuk menjadi mediator. Yayasan Lembaga Konsumen mengundang secara resmi kedua belah pihak untuk mediasi.

6. Yayasan Lembaga Konsumen memberi kesempatan kepada kedua belah pihak untuk menjelaskan duduk perkara yang sebenarnya tanpa boleh dipotong oleh pihak lain sebelum pihak pertama selesai memberikan penjelasan. Setelah masing-masing menyampaikan masalahnya, maka Yayasan Lembaga Konsumen memberikan waktu untuk klarifikasi dan koreksi tentang apa yang disampaikan oleh masing-masing pihak.

7. Setelah permasalahannya diketahui, maka masing-masing pihak berhak menyampaikan opsi atau tuntutan yang diinginkan, sekaligus melakukan negosiasi atas opsi atau tuntutan tersebut untuk mencapai kesepakatan. Jika kedua belah pihak telah sepakat, maka isi kesepakatan dituangkan dalam Berita Acara Kesepakatan.

8. Tahap akhir adalah mengimplementasikan hasil kesepakatan. Dalam penyelesaian suatu kasus secara mediasi, terdapat dua kemungkina yaitu: terjadinya kesepakatan yang berarti kasus selesai atau deadlock (tidak terjadi kesepakatan), jika terjadi deadlock maka penyeleseaian sengketa melalui jalur litigasi.

Mengenai peraturan perundang-undangan yang bertujuan untuk memberikan perlindungan keamanan, keselamatan atau kesehatan kepada rakyat Indonesia saat ini dapat dijumpai dalam berbagai Undang-Undang, Peraturan Pemerintah dan berbagai Peraturan Pemerintah Peraturan Menteri ataupun Keputusan Menteri. Peraturan Perundang-undangan tersebut antara lain seperti:

a. KUH Pidana Pasal 202, 203, 204, 205, 263, 364, 266, 382 bis, 383, 388 dsb. Pasal-pasal tersebut mengatur sanksi pidana untuk perbuatan : memasukkan bahan berbahaya ke dalam sumber air minum umum; menjual, menawarkan, menerimakan atau membagikan barang yang dapat membahayakan jiwa atau kesehatan orang; memalsukan surat; melakukan persaingan curang; melakukan penipuan terhadap pembeli; menjual, menawarkan atau menyerahkan makanan, minuman dan obatobatan palsu.

b. Kitab Undang-Undang Hukum Perdata Pasal 1473-1512; Pasal 1320-1338.Pasal-Pasal tersebut mengatur perbuatan yang berkaitan dengan perlindungan kepada pembeli dan perlindungan kepada pihak-pihak yang terkait dalam perjanjian. 
c. Ordonansi Bahan-Bahan Berbahaya Tahun 1949, Ordonansi yang menentukan larangan untuk setiap pemasukan pemb : uatan, pengangkutan, persediaan, penjualan, penyerahan, penggunaan dan pemakaian bahan berbahaya yang bersifat racun atau berposisi racun terhadap kesehatan manusia.

d. Undang-Undang Ordonasi Obat Keras Tahun 1949, Undang-undang ini memberikan kewenangan pengawasan oleh pemerintah terhadap pemasukan, pengeluaran, pengangkutan bahan-bahan obat keras yang akan diproduksi atau diedarkan.

e. Undang-Undang No. 10 Tahun 1961 tentang Barang. Undang-undang ini mengatur tentang standar barang.

f. Undang-undang No. 8 Tahun 1999 tentang Perlindungan Konsumen.

g. Undang-Undang No. 36 Tahun 2009 Tentang Kesehatan.

h. Peraturan Perundang-undangan yang maksudnya memberikan perlindungan dan dalam bentuk keputusan atau peraturan Menteri, dapat ditemui dalam Bidang kesehatan seperti produksi dan pendaftaran Makanan dan Minuman, wajib Daftar Makanan, Makanan Daluwarsa, Bahan Tambahan Makanan, Penandaan, label dan lain sebagainya.

Hak-hak konsumen di atur dalam Pasal 4 Undang-Undang Perlindungan Konsumen, adapun hak-hak konsumen tersebut adalah:

a. Hak mendapatkan kenyamanan, keamanan, dan keselamatan dalam mengomsumsi barang dan/atau jasa;

b. Hak untuk dapat memilih dan mendapatkan barang dan/atau jasa sesuai dengan nilai tukar dan kondisi serta jaminan yang dijanjikan;

c. Hak mendapatkan informasi yang benar, jelas dan jujur mengenai kondisi dan jaminan barang dan/atau jasa;

d. Hak didengar pendapat dan keluhannya atas barang dan/atau jasa yang digunakan;

e. Hak mendapatkan advokasi, perlindungan, dan upaya penyelesaian sengketa konsumen secara patut;

f. Hak mendapat pembinaan dan pendidikan bagi konsumen;

g. Hak diperlakukan atau dilayani secara benar dan jujur serta tidak diskriminatif;

h. Hak mendapatkan kompensasi, ganti rugi dan/atau penggantian, apabila barang dan/atau jasa yang diterima tidak sesuai dengan perjanjian atau tidak sebagaimana mestinya;

i. Hak yang diatur dalam ketentuan peraturan perundang- undangan lainnya.

Untuk mewujudkan perlindungan terhadap konsumen maka setiap produk pangan khususnya produk makanan wajib memenuhi standar keamanan dan mutu pangan, sebagaimana diatur dalam Pasal 111 Undang-Undang tentang Kesehatan bahwa makanan dan minuman yang dipergunakan untuk masyarakat harus didasarkan pada standar dan/atau persyaratan kesehatan, dan hanya dapat diedarkan setelah mendapat izin edar sesuai dengan ketentuan peraturan perundang-undangan. Hal tersebut dilakukan untuk memenuhi hak konsumen yakni berhak atas kenyamanan, keamanan dan keselamatan dalam mengonsumsi barang dan/atau jasa.

Untuk melindungi hak konsumen tersebut maka pada Pasal 87 Undang-Undang tentang Pangan mengatur bahwa pemerintah dapat menetapkan persyaratan supaya pangan diuji di laboratorium terlebih dahulu sebelum diedarkan, pengujian tersebut dilaksanakan di laboratorium yang ditunjuk oleh pemerintah dan/atau yang telah memperoleh akreditasi dari pemerintah. Upaya pengujian terhadap pangan sebelum beredar dan bahkan pangan yang telah beredar harus dilakukan karena tidak sedikit pelaku usaha yang belum menjalankan 
Kosmik Hukum Vol. 20 No. 2 (2020): 91-103

E-ISSN: 2655-9242 | P-ISSN: 1411-9781

DOI: $10.30595 /$ kosmikhukum.v20i2.6883

kewajibannya. Kewajiban pelaku usaha tersebut diatur dalam UUPK Pasal 7 huruf (a) yaitu kewajiban pelaku usaha adalah beritikad baik dalam melakukan kegiatan usahanya. Pada Pasal 62 angka 1 UUPK ditentukan bahwa pelaku usaha yang melanggar ketentuan sebagaimana dimaksud dalam Pasal 8, Pasal 9, Pasal 10, Pasal 13 ayat (2), Pasal 15, Pasal 17 ayat (1) huruf a, huruf b, huruf $c$, huruf e, ayat (2), dan Pasal 18 dipidana dengan pidana penjara paling lama 5 (lima) tahun atau pidana denda paling banyak Rp.2.000.000.000,00 (dua miliar rupiah).

\section{Penutup}

Untuk mewujudkan perlindungan hukum bagi konsumen maka setiap produk pangan wajib memenuhi standar keamanan dan mutu pangan, sebagaimana diatur dalam Pasal 111 Undang-Undang tentang Kesehatan bahwa makanan dan minuman yang dipergunakan untuk masyarakat harus didasarkan pada standar dan/atau persyaratan kesehatan, dan hanya dapat diedarkan setelah mendapat izin edar sesuai dengan ketentuan peraturan perundangundangan.

\section{Daftar Pustaka}

Burhan Ashshofa, Metode Penelitian Hukum, (Rineka Cipta, Jakarta, 2004)

Chatarina Wariyah dan Sri Hartati Candra Dewi, "Penggunaan Pengawet dan Pemanis Buatan Pada Pangan Jajanan Anak Sekolah (PJAS) di Wilayah Kabupaten Kulon Progo DIY", Agritech, Vol. 33 No. 2, Mei 2013

Endang Sutrisno and Hanari Fajarini, "Legal Culture Of Pharmacist In The Perspective Of Pharmaceutical Services Standard In Pharmacies", Jurnal Dinamika Hukum, Volume 16, No. 2, September 2016

Endar Puspawiningtyas, Regawa Bayu Pamungkas, Alwani Hamad, "Upaya Meningkatkan Pengetahuan Bahan Tambahan Pangan Melalui Pelatihan Deteksi Kandungan Formalin dan Boraks", Jurnal Pengabdian dan Pemberdayaan Masyarakat (JPPM, Volume 1 Nomor 1, Maret 2017

Imam Adi Sanjaya, 2018, "Perlindungan Hukum Komsumen Terhadap Produk Yang Tidak Bersersertifikat (Studi Di Dinas Perdagangan Dan Dinas Pertanian Dan Ketahanan Pangan Kota Malang)", Jurusan Hukum Bisnis Syariah Fakultas Syariah Universitas Islam Negeri Maulana Malik Ibrahim Malang

Kitab Undang-undang Hukum Perdata

Kitab Undang-undang Hukum Pidana

Leha Julaeha, Ai Nurhayati, Ai Mahmudatussa'adah, "Penerapan Pengetahuan Bahan Tambahan Pangan Pada Pemilihan Makanan Jajanan Mahasiswa Pendidikian Tata Boga UPI", Jurnal Media Pendidikan, Gizi dan Kuliner, Volume 5 Nomo 1, April 2016, hlm. 18

Nurdin Nurdin dan Budi Utomo, Tinjauan Penggunaan Bahan Tambahan Pangan Pada Makanan Jajan Anak Sekolah, Jurnal Riset Kesehatan, Volume 7 Nomor 2, 2018, hlm. 85

Peraturan Kepala Badan Pengawas Obat dan Makanan RI Nomor 4 Tahun 2014 tentang Nama Bahan Tambahan Pangan, Atau Jenis Bahan Tambahan Pangan

Peraturan Kepala BPOM Nomor 73 Tahun 2013 tentang Batas Maksimum Penggunaan Bahan Tambahan Pangan Pewarna

Peraturan Menteri Kesehatan RI Nomor 33 Tahun 2012 tentang Bahan Tambahan Pangan

Peter Mahmud Marzuki, Penelitian Hukum, (Prenada Media, Jakarta, 2005)

Ronny Hanitijo Soemitro, Metodologi Penelitian Hukum dan Jurimetri, (Ghalia Indonesia, Jakarta, 1999) 
Sahmadi Miru, Prinsip-Prinsip Perlindungan Hukum Bagi Konsumen Di Indonesia, (Rajawali Pers, Jakarta, 2013)

Siti Fatimah, Perlindungan Hukum Hak Atas Informasi Dan Keamanan Dalam Mengkonsumsi Makanan Yang Mengandung Zat Pewarna Tekstil Rhodamin B Berdasarkan Undang- Undang Nomor 8 Tahun 1999 Tentang Perlindungan Konsumen Di Kota Yogyakarta, (UIN Sunan Kalijaga, Yogyakarta, 2015)

Undang-undang Nomor 36 Tahun 2009 tentang Kesehatan

Undang-undang Nomor 8 Tahun 1999 tentang Perlindungan Konsumen

Wisnu Cahyadi, 2009, Analisis dan Aspek Kesehatan Bahan Tambahan Pangan, Bumi Aksara, Jakarta 